The Cryosphere Discuss., doi:10.5194/tc-2016-65, 2016

Manuscript under review for journal The Cryosphere

Published: 20 April 2016

(c) Author(s) 2016. CC-BY 3.0 License.

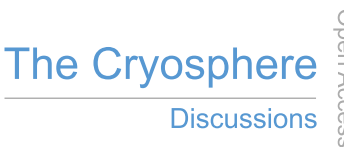

(c) (1)

\title{
Controls on the distribution of the soil organic matter in mountain permafrost regions on the north Qinghai-Tibet Plateau
}

Cuicui Mu, Tingjun Zhang, Xiankai Zhang, Hong Guo, Bin Cao, Lili Li, Hang Su, Xiaoqing Peng

5

Key Laboratory of Western China's Environmental Systems (Ministry of Education), College of Earth and Environmental Sciences, Lanzhou University, Lanzhou, 730000, China

Correspondence to: Tingjun Zhang (tjzhang@lzu.edu.cn) 
The Cryosphere Discuss., doi:10.5194/tc-2016-65, 2016

Manuscript under review for journal The Cryosphere

Published: 20 April 2016

(c) Author(s) 2016. CC-BY 3.0 License.

Abstract. It has been known a large amount of soil organic carbon (SOC) have been accumulated over thousands of years and stored at considerable depths in permafrost regions, which could extent down tens of meters. Although the vegetation plays an important role in the distribution of SOC in upper 1 or $2 \mathrm{~m}$ soils, little is known about the determines of the organic carbon pools below these depths. We hypothesized that the SOM distribution and its chemical characteristics for different depths were determined by vegetation types and soil texture in mountain permafrost. To test the hypothesis, ten boreholes which were about $20 \mathrm{~m}$ depth under alpine swamp meadow (ASM), alpine meadow (AM) and alpine steppe (AS) were drilled in the permafrost regions on the northern Qinghai Tibetan Plateau. The results showed that the SOC stocks were highest over ASM, and lowest over AS for different depths. The soil textures were mainly silt loam over ASM, while varied with sandy loam, silt loam, and sand in AM. All the soils with higher fine-fractions have higher SOC contents than that in

20 coarse soils. Meanwhile, the $\mathrm{C} / \mathrm{N}$ ratios and carbon isotopes suggested that the SOC pools accompanied with fine-fractions soils under swamp meadow are more decomposable than those of coarse soils. Our results suggest and both the SOC stocks distribution and the chemical nature of organic matter are determined by the soil texture and vegetation types, and this rule is applicable for SOC distribution for the $20 \mathrm{~m}$ depth in mountain permafrost regions.

25 Keywords: mountain permafrost, soil texture, vegetation types, soil organic matter chemistry, C:N ratio, stable carbon isotopes

\section{Introduction}

Soil organic carbon (SOC) stored in permafrost regions will become accessible to microbial decomposition and may provide

30 a major source of greenhouse gases (Lee et al., 2012; Paré and Bedard - Haughn, 2013). In addition to the large pools of SOC in circum-Arctic regions, there are also high stocks of SOC in mountain permafrost regions (Hoffmann et al., 2014a; Hoffmann et al., 2014b). The heterogeneities (topography, soil hydrothermal conditions, aspect and vegetation type) result in a large variability of soil properties and thus large uncertainties in the SOC distribution (Hoffmann et al., 2014a).

In mountain permafrost regions, it has been showed that many factors such as precipitation (Yang et al., 2008),

35 permafrost, pedogenesis (Baumann et al., 2009), vegetation types (Wu et al., 2012), below ground biomass (Liu et al., 2012), soil moisture, and soil texture (Wu et al., 2016) may have effects on the SOC distribution for the upper 0-2 m soil layers, while little is known about the controlling factors for the SOC pools below these depths. In permafrost regions, the deep SOC pools are vulnerable to mobilization following global warming (Bockheim and Hinkel, 2007). A recent study showed that deep SOC in permafrost regions may greatly affect the carbon balance since these carbon pools can have great soil

40 respiration that are not compensated by inputs (Koven et al., 2015).

The chemical composition of organic matter is an important variable with respect to potential bioavailability in a warming future (Mueller et al., 2015). In circum-Arctic regions, it has been demonstrated that deep soil carbon in permafrost 
The Cryosphere Discuss., doi:10.5194/tc-2016-65, 2016

Manuscript under review for journal The Cryosphere

Published: 20 April 2016

(c) Author(s) 2016. CC-BY 3.0 License.

regions also has high microbial availability (Schuur et al., 2015). The $\mathrm{C} / \mathrm{N}$ ratio in soils provides an important information in how soils respond to environmental changes (Callesen et al., 2007) because highly decomposed organic matter has low C/N ratios (Werth and Kuzyakov, 2010). Stable carbon isotope analysis is an useful tool for gaining insight into biogeochemical processes involved in SOC degradation (Jones et al., 2010). ${ }^{12} \mathrm{C}$ is preferentially used by decomposers, which may lead to

${ }^{13} \mathrm{C}$ enrichment in the remaining SOC (Natelhoffer and Fry, 1988), consequently resulting in easily decomposable substances having less negative $\delta^{13} \mathrm{C}$ values. Therefore, the $\mathrm{C} / \mathrm{N}$ ratios, and $\delta^{13} \mathrm{C}$ values organic matter could be used to reveal the potential microbial decomposition of organic matter in permafrost regions.

As a typical mountain permafrost region, the Qinghai-Tibetan Plateau (QTP) is the largest middle and low latitude permafrost area. The QTP is extremely sensitive to global warming since the rate of climate warming could be amplified in high-mountain regions (Kang et al., 2010). For the permafrost regions on the QTP, most ground temperatures are slightly below $0^{\circ} \mathrm{C}$ (Zhao et al., 2010), so small increases in air temperature will cause rapid soil organic matter degradation (Ping et al., 2015). The SOC storage in the QTP is approximately $160 \mathrm{Pg} \mathrm{C}$ for the $150 \times 10^{4} \mathrm{~km}^{2}$ of the $0-25 \mathrm{~m}$ soils (Mu et al., 2015).

55 Of that, $132.3 \pm 76.8 \mathrm{Pg} \mathrm{C}$ is stored in soils below $3 \mathrm{~m}$. There are several reports to the distribution and SOM chemistry in the permafrost regions on the QTP (Hu et al., 2014; Wu et al., 2014), while little is known about the distribution of deep SOC and its chemistry.

The SOC pool in deep soils was accumulated thousands of years (Mu et al., 2014; Schuur et al., 2009). In many soils, the soil texture is related positively to SOC contents (Schimel et al., 1994), and also has important effects on soil hydro-thermal properties (Sugimoto et al., 2003). Moreover, soil texture also relates to vegetation types, soil moisture and even active layer thickness of permafrost (Wu et al., 2016). Based on the above understanding, we propose the following hypotheses: (1) the distribution of SOC in the soils including surface and deep layers is influenced by vegetation types and soil texture in the QTP; (2) there are significant differences in the characteristics of SOC under different vegetation types and different soil texture classes. These hypotheses were tested using soils from the northern QTP by analyzing the contents, C/N ratios and stable carbon isotopes.

\section{Materials and methods}

\subsection{Study area}

The study area is located in the Qilian Mountains at the upper reach of the Heihe River Basin in the northern QTP (Fig. 1).

70 The area belongs to a region of inland-river in a semi-arid area in China and was characterized by prevailing westerlies (Wang et al., 2013). The annual air temperature of the basin ranges is less than $2{ }^{\circ} \mathrm{C}$. The annual precipitation is about $400 \mathrm{~m}$, and the mean annual evaporation is 1,080 $\mathrm{mm}$ (Peng et al., 2013). 
The Cryosphere Discuss., doi:10.5194/tc-2016-65, 2016

Manuscript under review for journal The Cryosphere

Published: 20 April 2016

(c) Author(s) 2016. CC-BY 3.0 License.

The distribution of permafrost in the Heihe River Basin is mainly controlled by elevation, and the lower limit of the elevation of permafrost was approximately 3,650 m (Wang et al., 2013). There are three main vegetation types in the study area: alpine swamp meadow, alpine meadow and alpine steppe, and the dominant plants are Kobresia tibetic, Kobresia pygmaea, and Kobresia humilis. The geological stratigraphy of the study area is quaternary.

\subsection{Field sampling and monitoring}

The SOC pools in permafrost regions were usually calculated according to distribution of vegetation types (Mu et al., 2015; Ping et al., 2008). In the permafrost regions on the QTP, there are mainly three vegetation types, i.e., alpine steppe (AS), 80 alpine meadow (AM), and alpine swamp meadow (ASM) (Ding et al., 2016; Hu et al., 2014; Wu et al., 2016). Therefore, ten deep boreholes, including AS, AM, and ASM were drilled at elevations of 3,615-4,138 m in 2011-2014 (Fig. 1). The soil parent materials for PT sites (PT4, 5, 6, 7, 9, 10, 11, 12) were alluvium, and these sites were located in a mountain basin with a gradually slope. The parent materials for EB1 and EB2 sites were colluvium, located in a mountain valley. The geographic information of these boreholes is shown in Table 1. The vegetation, permafrost and basic soil properties were shown in

85 Table 2. Overall, the vegetation type of PT4, PT5, PT6 and PT7 was AM, that of PT9, EB1, and EB2 was ASM, and that of PT10, PT11 and PT12 was AS. The borehole site of PT11 was located in a seasonally frozen ground area, and the other borehole sites were located in permafrost areas. The sites of PT10, PT11, and PT12 have the same aspect, slope, topography, elevation and well drainage conditions, and are considered as the boundaries of permafrost and non-permafrost. The soils in the study area were largely alkaline with $\mathrm{pH}$ values of 8.53-8.84, with the exception for EB1 and EB2. The conductivities of

90 the soil suspensions ranged from 0.95 to $1.33 \mathrm{~ms} \mathrm{~cm}^{-1}$ (Table 2).

The depths of the drilled boreholes were approximately $20 \mathrm{~m}$. The collected core diameter was about $15 \mathrm{~cm}$. The depths of samples collected at PT6, PT9, EB1 and EB2 were 9.0, 7.0, 6.0 and $5.0 \mathrm{~m}$ because below these depths there were rock layers. For PT12, the soil samples in the upper $2 \mathrm{~m}$ were not available because of the high gravel contents in this layer. For all other sites, each 30-40-cm-long drilled core was recovered, photographed, wrapped, labeled on the both ends of the core. These cores were stored in a freezer at $-20^{\circ} \mathrm{C}$. Upon returning to the laboratory at Lanzhou University, the samples were transferred to an ultralow-temperature freezer.

\subsection{Laboratory analyses}

\subsubsection{Basic soil analyses}

Soil bulk density was determined by calculating the volume of a section from the frozen core before drying the section and determining its mass. Total water content was determined by drying the soils at $105^{\circ} \mathrm{C}$ for $8 \mathrm{~h}$ and measuring the soil weight before and after drying. The $\mathrm{pH}$ values and conductivities of the soil suspensions (1:2.5 soil:water ratio) were measured with a $\mathrm{pH}$ meter and conductivity meter. The percent by weight of rock fragment $(>2 \mathrm{~mm})$ was calculated with the oven-dried 
The Cryosphere Discuss., doi:10.5194/tc-2016-65, 2016

Manuscript under review for journal The Cryosphere

Published: 20 April 2016

(c) Author(s) 2016. CC-BY 3.0 License.

samples. The soils particle distribution was separated into three fractions: clay $(<2 \mu \mathrm{m})$, silt $(2-50 \mu \mathrm{m})$, and sand $(50 \mu \mathrm{m}-2$ $\mathrm{mm}$ ) by a laser diffraction instrument (Malvern Mastersizer 2000, Malvern, UK).

The SOC and total nitrogen (TN) of pulverized homogenized samples were quantified by dry combustion using a Vario EL elemental analyzer (Elemental, Hanau, Germany). The SOC contents for EB1 and EB2 sites were cited from previous study(Mu et al., 2015). To measure the SOC, $0.5 \mathrm{~g}$ dry soil samples were pretreated with $\mathrm{HCl}\left(10 \mathrm{~mL}, 1 \mathrm{~mol} \mathrm{~L}^{-1}\right)$ for $24 \mathrm{~h}$ to remove carbonate. The $\mathrm{C} / \mathrm{N}$ ratios were calculated using the mass ratio between SOC and TN (Ping et al., 2015).

\subsubsection{Isotope analyses}

The stable carbon isotopes of EB1 and EB2 were cited from previous study (Mu et al., 2014). The stable carbon isotopes of the SOC of other samples were analyzed using an OI Analytical Analyzer with an analytical precision of $\pm 0.2 \%$ (Picarro, California, USA). The samples were treated with hydrochloric acid to remove inorganic carbon prior to analysis. The results are based on the mean of three replicates for each sample and are expressed as $\delta$-values relative to the VPDB $\delta^{13} \mathrm{C}$ standard. The $\delta$-values are defined as follows:

$$
\delta^{13} C \%=\left[\left(R_{\text {sample }} / R_{\text {standard }}\right)-1\right] \times 1000
$$

where $\mathrm{R}_{\text {sample }}$ and $\mathrm{R}_{\text {standard }}$ are the ${ }^{13} \mathrm{C} /{ }^{12} \mathrm{C}$ ratios of the samples and standard, respectively.

\subsubsection{Statistical analyses}

The data presented in this study are the average values. The linear regression was performed using ANOVA.

\section{Results}

\subsection{Distribution of soil organic carbon and C:N ratios}

The distribution of SOC densities varied among different vegetation types and depth (Fig. 2). For the sites of ASM (PT9, EB1 and EB2), the SOC densities were much higher than those of AM, although there was a decreasing trend along with depth at EB2. The mean SOC densities for the sites ranged from 0.4 to $22.4 \mathrm{~kg} \mathrm{~m}^{-3}$, with the highest value appeared at ASM.

125 The lowest SOC densities were recorded at the sites in AS sites (PT10, PT11 and PT12), with mean values of less than 1.0 $\mathrm{kg} \mathrm{m}^{-3}$.

For all the measured samples, the $\mathrm{C} / \mathrm{N}$ ratios ranged from 2.26 to 73.04 . The distribution of $\mathrm{C} / \mathrm{N}$ ratios with depth followed a similar trend to the SOC densities at the sites of PT4-7 (Fig. 2). The average values of C:N ratios in permafrost boreholes were 19.98, 17.65, 13.61, 13.44 for the sites of PT4, PT5, PT6, PT7, respectively. For the sites of ASM, the C:N ratios for PT9, EB1, and EB2 were 11.03, 7.59, and 6.45. 
The Cryosphere Discuss., doi:10.5194/tc-2016-65, 2016

Manuscript under review for journal The Cryosphere

Published: 20 April 2016

(c) Author(s) 2016. CC-BY 3.0 License.

\subsection{Relationship between soil organic carbon and $\mathrm{C} / \mathrm{N}$ ratios and stable carbon isotopes}

For the samples at different depths, the $\mathrm{C} / \mathrm{N}$ ratio and SOC content had a weak positive relationship for the ASM sites $\left(r^{2}=0.028\right.$, p<0.05, Fig. 3a), while had a higher correlation for AS and AM sites $\left(r^{2}=0.522, p<0.001\right.$, Fig. $\left.3 b\right)$.

135 The stable carbon isotope $\left(\delta^{13} \mathrm{C} \%\right.$ ) largely varied from $-29.9 \%$ to $-22.8 \%$ in the samples with an exception for some deep samples collected at EB2 (below $3.5 \mathrm{~m}$, and the soil texture belongs to sand). Overall, there were significant negative relationships between $\mathrm{C} / \mathrm{N}$ ratios and $\delta^{13} \mathrm{C} \%$ values both for ASM sites (Fig. 3c) and AS/AM sites (Fig. 3d).

\subsection{Relationship between SOC and environmental factors}

140 There was no significant correlation between the SOC content and total water content for ASM sites (Fig. 4a), while a significantly positive relationship was found in AS and AM sites (Fig. 4b). Significant negative relationships were found between SOC content and bulk density for the two groups (Fig. 4c and Fig. 4d).

According to the soil particle distribution, the soils from the sampling sites belong to the texture of sand, loamy sand, sandy loam, and silt loam. The loamy sands were only recorded in the upper $2 \mathrm{~m}$ layers at PT4, and the silt loams were recorded in

145 the most soils of ASM sites (PT9, EB1, and EB2), AM site of PT6, and upper $10 \mathrm{~cm}$ layer of PT5. It is clearly that the silt loams of ASM sites had the highest SOC densities, followed by the sandy loams and silt loams of AM sites. The sands under AS sites had higher SOC densities than that of ASM, while the lowest SOC densities appeared in the sands of AS sites (Fig.5).

For all the samples, the SOC contents were significantly correlated to the clay contents $\left(R^{2}=0.232, p<0.001, n=158\right)$. The

150 correlation between SOC and clay in ASM sites $\left(R^{2}=0.562, p<0.001\right)$ were higher than those of AM and AS sites $\left(R^{2}=0.139\right.$, $\mathrm{p}<0.001$ ) (Fig. 6).

According to the relationship between the SOC contents and depth, total water content, bulk density, and clay content, the best regression models are displayed as follows:

$\operatorname{SOC}(\%)=0.092 \times$ Moisture $-0.214 \times$ Depth $-0.201 \times$ Gravel $+0.672 \times$ Clay $\left(R^{2}=0.566, \mathrm{p}<0.001, \mathrm{n}=158\right)$.

\section{4. Discussion}

The SOC densities of the three vegetation types are similar with of previous reports in the eastern (Ding et al., 2016; Hu et al., 2014; Yang et al., 2008), middle (Baumann et al., 2009; Shang et al., 2016), and western (Wu et al., 2012; Wu et al., 2016) part of the QTP, although these results mainly focused on the SOC within $2 \mathrm{~m}$ or $3 \mathrm{~m}$ depths. For deep layers, the SOC densities are also similar with the results from the boreholes which distributed along a latitude gradient (Mu et al., 160 2015). Therefore, the sampling area can be considered as representative of SOC distribution for the QTP. The SOC densities 
The Cryosphere Discuss., doi:10.5194/tc-2016-65, 2016

Manuscript under review for journal The Cryosphere

Published: 20 April 2016

(c) Author(s) 2016. CC-BY 3.0 License.

of the vegetation types of AM sites (PT4, PT5, PT6, PT7) were higher than those of AS sites (PT10, PT11 and PT12), while lower than those of ASM sites (PT9, EB1, and EB2). This finding was in agreement with the previous results that vegetation types affect the SOC contents (Jobbágy and Jackson, 2000; Wu et al., 2012). It is worth mentioning that this pattern was not only limited to the upper 2 or $3 \mathrm{~m}$ layers (which were usually studied in previous reports) but also extended to the deep permafrost layers, which could reach to $5 \mathrm{~m}$ depth or more (PT6, PT9, EB1, EB2) and even about $20 \mathrm{~m}$ depth (PT4, PT5, PT7). In Arctic regions, yedoma deposits and river deltas had been recognized have thick soil layers with high organic carbon (Hugelius et al., 2014; Tarnocai et al., 2009). Our results showed that the vegetation types potentially have great effects on SOC distribution in deep layers in mountain permafrost areas on the north QTP.

For the same vegetation type of AM, the SOC densities in the active layer at sites PT4, PT5, PT6 and PT7 had a wide range from 4.77 to $11.12 \mathrm{~kg} \mathrm{~m}^{-3}$, which could be related to topography, elevation, aspect and slope (Hoffmann et al., 2014a; Thompson and Kolka, 2005). Although the SOC densities at the AS sites (PT10, PT11 and PT12) showed a decreasing trends with depth in the active and permafrost layers, the SOC densities in the permafrost boreholes (PT4, PT5, PT6, PT7, PT9, EB1, and EB2) were still high in some deep layers. This shows that low temperature contributes to the preservation of SOM (Zimov et al., 2006). The results indicate that the vegetation types and permafrost in mountain permafrost regions have a significant effect on the vertical distribution of SOC both in active and permafrost layers.

The $\mathrm{C} / \mathrm{N}$ ratio showed significantly positive correlation to SOC contents when combined all the samples at different layers. The significant positive relationship between the $\mathrm{C} / \mathrm{N}$ ratios and SOC contents (Fig. $3 \mathrm{a}$ and $3 \mathrm{~b}$ ) was consistent with the notion that high $\mathrm{C} / \mathrm{N}$ ratios reflect a better preservation of SOM for the different depths (Andersson et al., 2012). This was corroborated by the relationships between soil water and SOC contents since higher soil water content will decrease the decomposition of organic carbon (Schlesinger and Andrews, 2000). The mean values of $\mathrm{C} / \mathrm{N}$ ratios at ASM sites were much lower than those of AM and AS sites. According to the global database of soils, the $\mathrm{C} / \mathrm{N}$ ratios for tundra were about 18 (Eswaran et al., 1993; Post et al., 1985). Therefore, the relative lower C/N ratios in the present study implies that SOC stored in the ASM will be easily decomposable and thus has great potential to produce greenhouse gases in the future.

The $\delta^{13} \mathrm{C}$ values largely ranged from $-29.6 \%$ to $-22.8 \%$ in the study area, which is within the range generally associated 185 with $\mathrm{C} 3$ peat-forming plants. The $\delta^{13} \mathrm{C} \%$ negatively correlated to SOC contents suggests that the lower microbial decomposition is one of the mechanisms for the accumulation of the SOC. For the sites of AM and AS in this study with good drainage, it was could be inferred that aerobic conditions that favor the selective loss of ${ }^{12} \mathrm{C}$ (Alewell et al., 2011) and thus the $\mathrm{C} / \mathrm{N}$ ratio was expected has a negative relationship with carbon isotope for the samples at different depths (Fig 3c, 3d). It worth mentioning that the $\delta^{13} \mathrm{C} \%$ values of the soils below $3.5 \mathrm{~m}$ at EB2 were much higher than other samples of

190 ASM sites. This could be explained by that the texture of sand greatly promoted the decomposition of SOM during the accumulation process of these carbon pools, and/or a change of vegetation from C4 plants to C3 plants at the depths of $3.5 \mathrm{~m}$ (Mu et al., 2014).

In our study, the clay content significantly correlated to the SOC contents. This is in agreement with the reports for the upper $2 \mathrm{~m}$ layers (Wu et al., 2016). This could be explained as that fine particles tend to stabilize and retain more organic 
The Cryosphere Discuss., doi:10.5194/tc-2016-65, 2016

Manuscript under review for journal The Cryosphere

Published: 20 April 2016

(c) Author(s) 2016. CC-BY 3.0 License.

(c) (1)

matter than coarser particle (Gregorich et al., 1994). In addition, fine particles have higher water holding capacity (GómezPlaza et al., 2001). In the three ASM sites, these factors were not significantly relationship between the SOC contents and gravel content, depth, and moisture, and there were even no gravels in the soils at EB1 and EB2. . Therefore, although these factors were appeared as independent factors for the SOC contents in the linear regression model, these factors largely reflected the SOC patterns in AS and AM sites.

\section{Conclusions}

The SOC distribution and the chemical characteristics of SOM under different vegetation types in mountain permafrost regions were investigated on the northern QTP. The vegetation types have an important effect on the SOC distribution in different soil layers which could reach to $20 \mathrm{~m}$ depth. Soil texture is another determinants for the SOC pools both in the active layer and permafrost, and the fine soil particle is favor to the accumulation of SOC. The higher $\mathrm{C} / \mathrm{N}$ ratios and lower stable carbon isotopes suggested the chemical nature of organic matter was also affected by vegetation types and soil texture, and the SOC pools accompanied with fine-fractions soils under swamp meadow are more decomposable than those of coarse soils. The result improves our understanding of SOC distribution, as well as provides new insights into evaluation the interaction the SOC pools and global warming in future.

\section{Acknowledgements}

This work was supported by the National Key Scientific Research Project (Grant 2013CBA01802), and the National Natural Science Foundation of China (Grants 91325202, 41330634). This work was also supported in part by the Open Foundations of State Key Laboratory of Frozen Soil Engineering (Grant SKLFSE201408), the State Key Laboratory of Cryospheric Sciences (Grant SKLCS-OP-2014-08) and the Fundamental Research Funds for the Central Universities (Grant lzujbky215 2015-123).

\section{References}

Alewell, C., Giesler, R., Klaminder, J., Leifeld, J., and Rollog, M.: Stable carbon isotopes as indicators for microgeomorphic changes in palsa peats, Biogeosciences Discussions, 8, 527-548, 2011.

220 Andersson, R. A., Meyers, P., Hornibrook, E., Kuhry, P., and Mörth, C. M.: Elemental and isotopic carbon and nitrogen records of organic matter accumulation in a Holocene permafrost peat sequence in the East European Russian Arctic, Journal of Quaternary Science, 27, 545-552, 2012.

Baumann, F., He, J. s., Schmidt, K., Kuehn, P., and Scholten, T.: Pedogenesis, permafrost, and soil moisture as controlling 
The Cryosphere Discuss., doi:10.5194/tc-2016-65, 2016

Manuscript under review for journal The Cryosphere

Published: 20 April 2016

(c) Author(s) 2016. CC-BY 3.0 License.

factors for soil nitrogen and carbon contents across the Tibetan Plateau, Global Change Biology, 15, 3001-3017, 2009.

Bockheim, J. and Hinkel, K.: The importance of "deep" organic carbon in permafrost-affected soils of arctic Alaska, Soil Science Society of America Journal, 71, 1889-1892, 2007.

Callesen, I., Raulund-Rasmussen, K., Westman, C. J., and Tau-Strand, L.: Nitrogen pools and C: N ratios in well-drained Nordic forest soils related to climate change and soil texture, Boreal Environment Research, 12, 681-692, 2007.

Ding, J., Li, F., Yang, G., Chen, L., Zhang, B., Liu, L., Fang, K., Qin, S., Chen, Y., Peng, Y., Ji, C., He, H., Smith, P., and

Yang, Y.: The permafrost carbon inventory on the Tibetan Plateau: a new evaluation using deep sediment cores, Global Change Biology, doi: 10.1111/gcb.13257, 2016. n/a-n/a, 2016.

Eswaran, H., Van Den Berg, E., and Reich, P.: Organic carbon in soils of the world, Soil science society of America journal, 57, 192-194, 1993.

Gómez-Plaza, A., Martınez-Mena, M., Albaladejo, J., and Castillo, V.: Factors regulating spatial distribution of soil water content in small semiarid catchments, Journal of Hydrology, 253, 211-226, 2001.

Gregorich, E., Monreal, C., Carter, M., Angers, D., and Ellert, B.: Towards a minimum data set to assess soil organic matter quality in agricultural soils, Canadian Journal of Soil Science, 74, 367-385, 1994.

Hoffmann, U., Hoffmann, T., Johnson, E., and Kuhn, N. J.: Assessment of variability and uncertainty of soil organic carbon in a mountainous boreal forest (Canadian Rocky Mountains, Alberta), Catena, 113, 107-121, 2014a.

Hoffmann, U., Hoffmann, T., Jurasinski, G., Glatzel, S., and Kuhn, N.: Assessing the spatial variability of soil organic carbon stocks in an alpine setting (Grindelwald, Swiss Alps), Geoderma, 232, 270-283, 2014b.

Hu, G., Fang, H., Liu, G., Zhao, L., Wu, T., Li, R., and Wu, X.: Soil carbon and nitrogen in the active layers of the permafrost regions in the Three Rivers' Headstream, Environmental Earth Sciences, 72, 5113-5122, 2014.

Hugelius, G., Strauss, J., Zubrzycki, S., Harden, J. W., Schuur, E., Ping, C.-L., Schirrmeister, L., Grosse, G., Michaelson, G.

245 J., and Koven, C. D.: Estimated stocks of circumpolar permafrost carbon with quantified uncertainty ranges and identified data gaps, Biogeosciences, 11, 6573-6593, 2014.

Jobbágy, E. G. and Jackson, R. B.: The vertical distribution of soil organic carbon and its relation to climate and vegetation, Ecological applications, 10, 423-436, 2000.

Jones, M. C., Peteet, D. M., and Sambrotto, R.: Late-glacial and Holocene $\delta 15 \mathrm{~N}$ and $\delta 13 \mathrm{C}$ variation from a Kenai Peninsula, Alaska peatland, Palaeogeogr. Palaeoclimatol. Palaeoecol., 293, 132-143, 2010.

Kang, S., Xu, Y., You, Q., Flügel, W.-A., Pepin, N., and Yao, T.: Review of climate and cryospheric change in the Tibetan Plateau, Environmental Research Letters, 5, 015101, 2010.

Koven, C. D., Lawrence, D. M., and Riley, W. J.: Permafrost carbon- climate feedback is sensitive to deep soil carbon decomposability but not deep soil nitrogen dynamics, Proceedings of the National Academy of Sciences, 112, 3752-3757, 2552015.

Lee, H., Schuur, E. A., Inglett, K. S., Lavoie, M., and Chanton, J. P.: The rate of permafrost carbon release under aerobic and anaerobic conditions and its potential effects on climate, Global Change Biology, 18, 515-527, 2012. 
The Cryosphere Discuss., doi:10.5194/tc-2016-65, 2016

Manuscript under review for journal The Cryosphere

Published: 20 April 2016

(c) Author(s) 2016. CC-BY 3.0 License.

Liu, W., Chen, S., Qin, X., Baumann, F., Scholten, T., Zhou, Z., Sun, W., Zhang, T., Ren, J., and Qin, D.: Storage, patterns, and control of soil organic carbon and nitrogen in the northeastern margin of the Qinghai-Tibetan Plateau, Environmental Research Letters, 7, 035401, 2012.

Mu, C., Zhang, T., Wu, Q., Peng, X., Cao, B., Zhang, X., Cao, B., and Cheng, G.: Organic carbon pools in permafrost regions on the Qinghai-Xizang (Tibetan) Plateau, The Cryosphere, 9, 479-486, 2015.

Mu, C., Zhang, T., Wu, Q., Zhang, X., Cao, B., Wang, Q., Peng, X., and Cheng, G.: Stable carbon isotopes as indicators for permafrost carbon vulnerability in upper reach of Heihe River basin, northwestern China, Quaternary International, 321, 71 $77,2014$.

Mueller, C. W., Rethemeyer, J., Kao-Kniffin, J., Loppmann, S., Hinkel, K. M., and Bockheim, J. G.: Large amounts of labile organic carbon in permafrost soils of northern Alaska, Glob. Chang. Biol., 21, 2804-2817, 2015.

Natelhoffer, K. and Fry, B.: Controls on natural nitrogen-15 and carbon-13 abundances in forest soil organic matter, Soil Science Society of America Journal, 52, 1633-1640, 1988.

Paré, M. C. and Bedard - Haughn, A.: Soil organic matter quality influences mineralization and GHG emissions in cryosols: a field - based study of sub - to high Arctic, Global change biology, 19, 1126-1140, 2013.

Peng, X., Zhang, T., Pan, X., Wang, Q., Zhong, X., Wang, K., and Mu, C.: Spatial and temporal variations of seasonally frozen ground over the heihe river basin of Qilian Mountain in Western China, Advances in Earth Science, 28, 497-508, 2013.

275 Ping, C.-L., Michaelson, G. J., Jorgenson, M. T., Kimble, J. M., Epstein, H., Romanovsky, V. E., and Walker, D. A.: High stocks of soil organic carbon in the North American Arctic region, Nature Geoscience, 1, 615-619, 2008.

Ping, C., Jastrow, J., Jorgenson, M., Michaelson, G., and Shur, Y.: Permafrost soils and carbon cycling, Soil, 1, 147-171, 2015.

Post, W. M., Pastor, J., Zinke, P. J., and Stangenberger, A. G.: Global patterns of soil nitrogen storage, Nature, 317, 613-616, 1985.

Schimel, D. S., Braswell, B., Holland, E. A., McKeown, R., Ojima, D., Painter, T. H., Parton, W. J., and Townsend, A. R.: Climatic, edaphic, and biotic controls over storage and turnover of carbon in soils, Global biogeochemical cycles, 8, 279293, 1994.

Schlesinger, W. H. and Andrews, J. A.: Soil respiration and the global carbon cycle, Biogeochemistry, 48, 7-20, 2000.

285 Schuur, E. A., McGuire, A. D., Schadel, C., Grosse, G., Harden, J. W., Hayes, D. J., Hugelius, G., Koven, C. D., Kuhry, P., Lawrence, D. M., Natali, S. M., Olefeldt, D., Romanovsky, V. E., Schaefer, K., Turetsky, M. R., Treat, C. C., and Vonk, J. E.: Climate change and the permafrost carbon feedback, Nature, 520, 171-179, 2015.

Schuur, E. A., Vogel, J. G., Crummer, K. G., Lee, H., Sickman, J. O., and Osterkamp, T. E.: The effect of permafrost thaw on old carbon release and net carbon exchange from tundra, Nature, 459, 556-559, 2009.

290 Shang, W., Wu, X., Zhao, L., Yue, G., Zhao, Y., Qiao, Y., and Li, Y.: Seasonal variations in labile soil organic matter fractions 
The Cryosphere Discuss., doi:10.5194/tc-2016-65, 2016

Manuscript under review for journal The Cryosphere

Published: 20 April 2016

(c) Author(s) 2016. CC-BY 3.0 License.

in permafrost soils with different vegetation types in the central Qinghai-Tibet Plateau, Catena, 137, 670-678, 2016.

Sugimoto, A., Naito, D., Yanagisawa, N., Ichiyanagi, K., Kurita, N., Kubota, J., Kotake, T., Ohata, T., Maximov, T., and Fedorov, A.: Characteristics of soil moisture in permafrost observed in East Siberian taiga with stable isotopes of water, Hydrological Processes, 17, 1073-1092, 2003.

295 Tarnocai, C., Canadell, J., Schuur, E., Kuhry, P., Mazhitova, G., and Zimov, S.: Soil organic carbon pools in the northern circumpolar permafrost region, Global biogeochemical cycles, 23, GB2023, 2009.

Thompson, J. A. and Kolka, R. K.: Soil carbon storage estimation in a forested watershed using quantitative soil-landscape modeling, Soil Science Society of America Journal, 69, 1086-1093, 2005.

Wang, Q., Zhang, T., Wu, J., Peng, X., Zhong, X., Mou, C., Wang, K., Wu, Q., and Cheng, G.: Investigation on permafrost distribution over the upper reaches of the Heihe River in the Qilian Mountains, Journal of Glaciology and Geocryology, 35, 19-25, 2013.

Werth, M. and Kuzyakov, Y.: ${ }^{13} \mathrm{C}$ fractionation at the root-microorganisms-soil interface: a review and outlook for partitioning studies, Soil Biology and Biochemistry, 42, 1372-1384, 2010.

Wu, X., Fang, H., Zhao, L., Wu, T., Li, R., Ren, Z., Pang, Q., and Ding, Y.: Mineralisation and changes in the fractions of

305 soil organic matter in soils of the Permafrost Region, Qinghai - Tibet Plateau, China, Permafrost and Periglacial Processes, 25, 35-44, 2014.

Wu, X., Zhao, L., Chen, M., Fang, H., Yue, G., Chen, J., Pang, Q., Wang, Z., and Ding, Y.: Soil organic carbon and its relationship to vegetation communities and soil properties in permafrost areas of the Central Western Qinghai-Tibet Plateau, China, Permafrost and Periglacial Processes, 23, 162-169, 2012.

310 Wu, X., Zhao, L., Fang, H., Zhao, Y., Smoak, J. M., Pang, Q., and Ding, Y.: Environmental controls on soil organic carbon and nitrogen stocks in the high - altitude - arid western Qinghai - Tibetan Plateau permafrost region, Journal of Geophysical Research: Biogeosciences, 121, 176-187, 2016.

Yang, Y., Fang, J., Tang, Y., Ji, C., Zheng, C., He, J., and Zhu, B.: Storage, patterns and controls of soil organic carbon in the Tibetan grasslands, Global Change Biology, 14, 1592-1599, 2008.

315 Zhao, L., Wu, Q., Marchenko, S., and Sharkhuu, N.: Thermal state of permafrost and active layer in Central Asia during the International Polar Year, Permafrost and Periglacial Processes, 21, 198-207, 2010.

Zimov, S., Davydov, S., Zimova, G., Davydova, A., Schuur, E., Dutta, K., and Chapin, F.: Permafrost carbon: Stock and decomposability of a globally significant carbon pool, Geophysical Research Letters, 33, L20502, 2006. 
The Cryosphere Discuss., doi:10.5194/tc-2016-65, 2016

Manuscript under review for journal The Cryosphere

Published: 20 April 2016

(c) Author(s) 2016. CC-BY 3.0 License. 
The Cryosphere Discuss., doi:10.5194/tc-2016-65, 2016

Manuscript under review for journal The Cryosphere

Published: 20 April 2016

(c) Author(s) 2016. CC-BY 3.0 License.

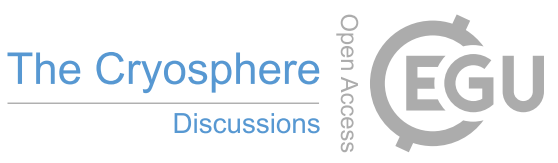

(c) (i)

Table 2 Vegetation and selected soil properties in upper reach of the Heihe River basin

\begin{tabular}{|c|c|c|c|c|c|c|}
\hline Site & $\begin{array}{c}\text { Vegetation } \\
\text { types }\end{array}$ & $\begin{array}{l}\text { Vegetation } \\
\text { cover } \%\end{array}$ & $\begin{array}{c}\text { Dominant } \\
\text { species }\end{array}$ & $\begin{array}{l}\text { Soil } \\
\text { pH }\end{array}$ & $\begin{array}{l}\text { Conductivity( } \\
\qquad \mathrm{ms} \mathrm{cm}^{-1} \text { ) }\end{array}$ & $\begin{array}{l}\text { Conductivity( } \\
\left.\qquad \mathrm{ms} \mathrm{cm}^{-1}\right)\end{array}$ \\
\hline PT4 & $\mathrm{AM}$ & 94 & Kobresia & 8.53 & 1.11 & 1.11 \\
\hline PT5 & $\mathrm{AM}$ & 90 & $\begin{array}{c}\text { pygmaea } \quad \text { C. B. } \\
\text { Clarke }\end{array}$ & 8.84 & 0.95 & 0.95 \\
\hline PT6 & $\mathrm{AM}$ & 80 & Ajania tibetica & 8.64 & 1.05 & 1.05 \\
\hline PT7 & $\mathrm{AM}$ & 85 & $\begin{array}{c}\text { Rhodiola } \\
\text { subopposita }\end{array}$ & 8.70 & 1.09 & 1.09 \\
\hline PT9 & ASM & 96 & K.tibetica Maxim & 8.65 & 1.12 & 1.12 \\
\hline PT10 & AS & 87 & K. humilis & 8.76 & 1.14 & 1.14 \\
\hline PT11 & AS & 78 & (C. A. Mey. ) & 8.61 & 1.03 & 1.03 \\
\hline PT12 & AS & 75 & Serg. & 8.80 & 1.83 & 1.83 \\
\hline EB1 & ASM & 95 & K.tibetica Maxim & 6.58 & 1.02 & 1.02 \\
\hline EB2 & ASM & 95 & K.tibetica Maxim & 7.44 & 1.33 & 1.33 \\
\hline
\end{tabular}

ASM: alpine swamp meadow; AM: alpine meadow; AS: alpine steppe 
The Cryosphere Discuss., doi:10.5194/tc-2016-65, 2016

Manuscript under review for journal The Cryosphere

Published: 20 April 2016

(c) Author(s) 2016. CC-BY 3.0 License.
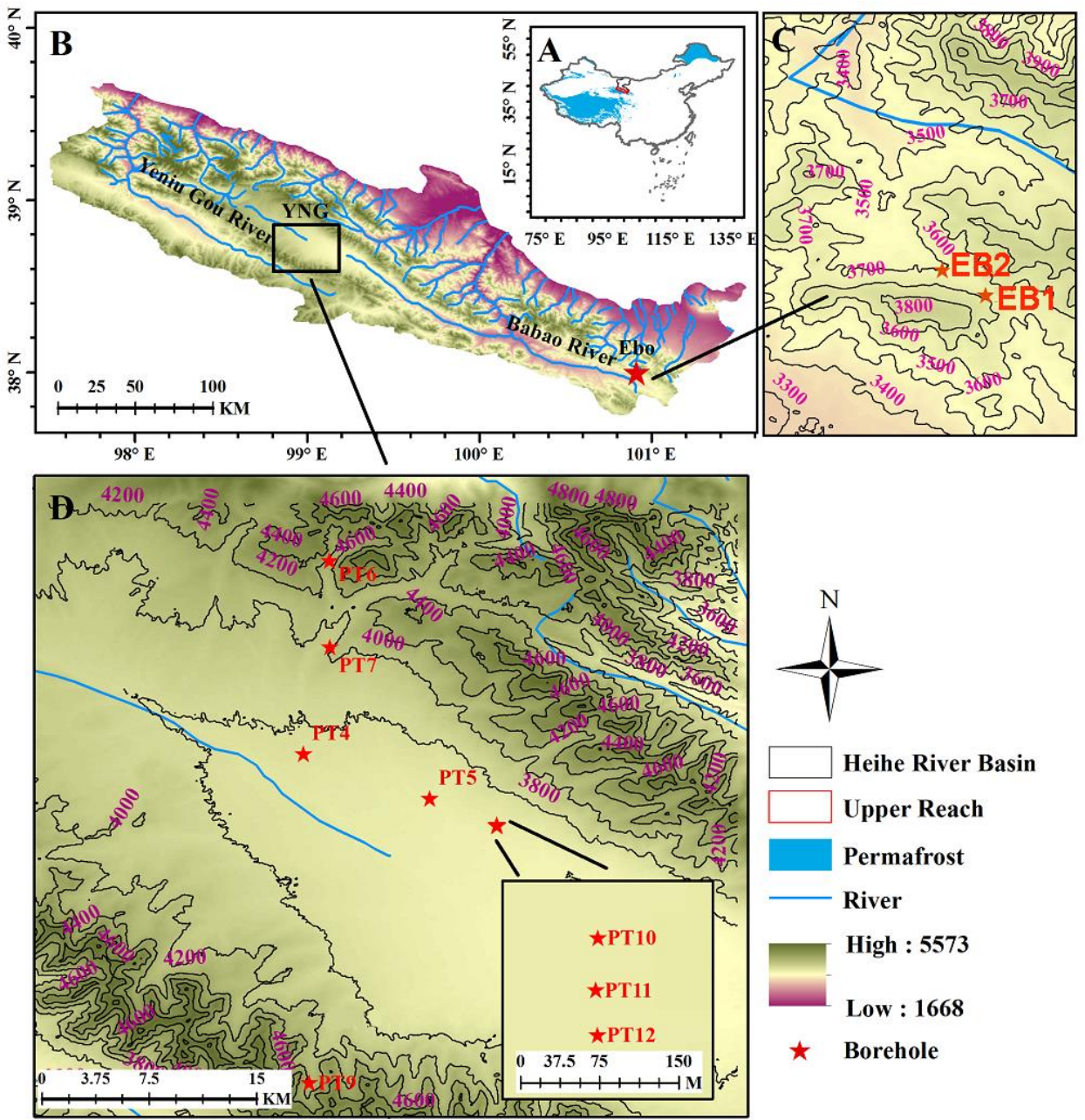

Figure 1 Location of permafrost borehole sites in upper reach of the Heihe River, northern Qinghai Tibetan

Plateau 
The Cryosphere Discuss., doi:10.5194/tc-2016-65, 2016

Manuscript under review for journal The Cryosphere

Published: 20 April 2016

(c) Author(s) 2016. CC-BY 3.0 License.

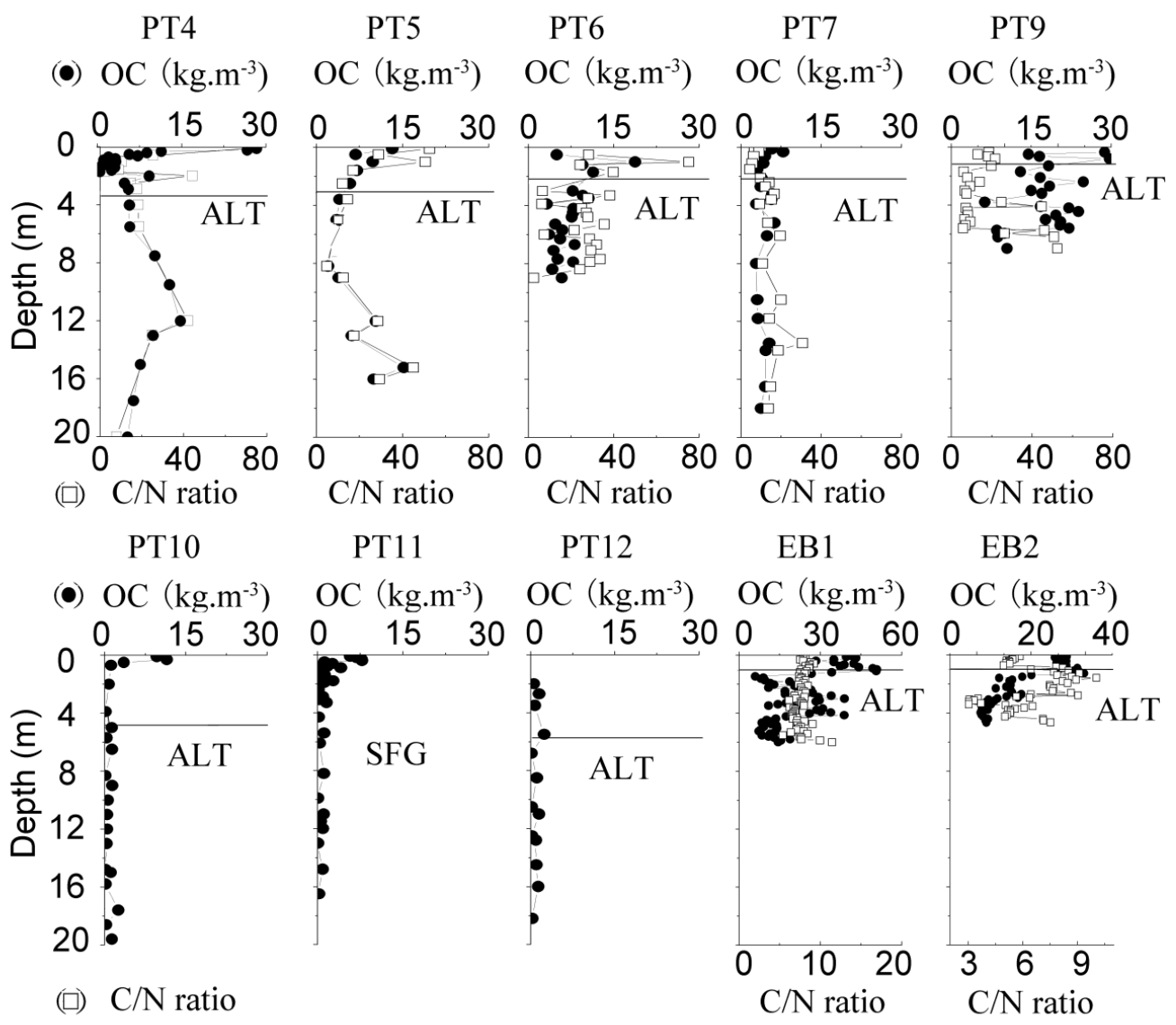

Figure 2 Distribution of soil organic carbon densities and C/N ratios with depth at all sites (the nitrogen data were not available for PT10, PT11, and PT12) (OC, soil organic carbon; ALT, active layer thickness) 
The Cryosphere Discuss., doi:10.5194/tc-2016-65, 2016

Manuscript under review for journal The Cryosphere

Published: 20 April 2016

(c) Author(s) 2016. CC-BY 3.0 License.
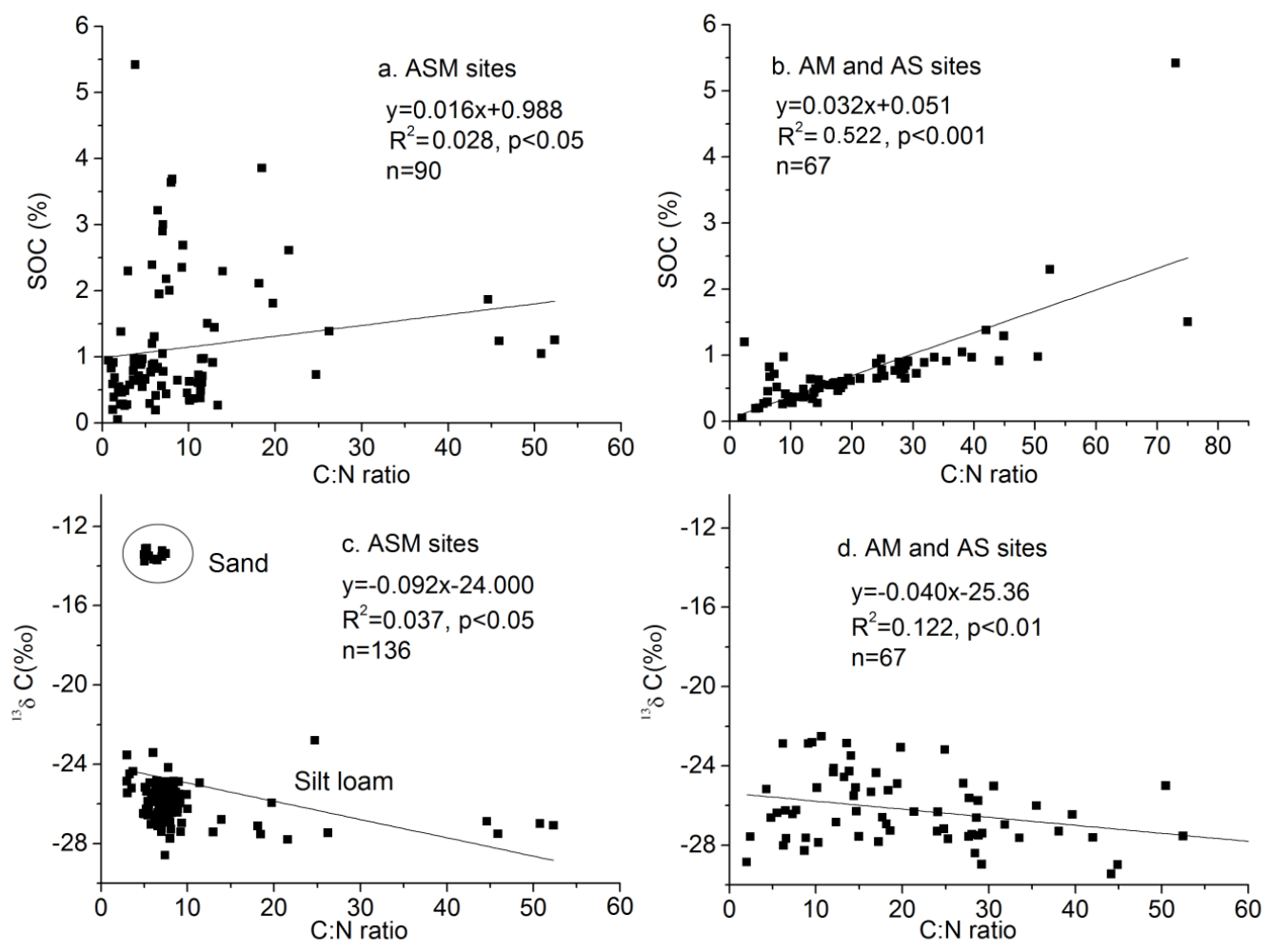

Figure 3 Correlations between SOC content, stable carbon isotope $\left(\delta^{13} \mathrm{C} \%\right)$ and $\mathrm{C}: \mathrm{N}$ ratio for ASM, AS and AM sites (ASM: alpine swamp meadow; AS: Alpine steppe; AM: Alpine meadow) 
The Cryosphere Discuss., doi:10.5194/tc-2016-65, 2016

Manuscript under review for journal The Cryosphere

Published: 20 April 2016

(c) Author(s) 2016. CC-BY 3.0 License.
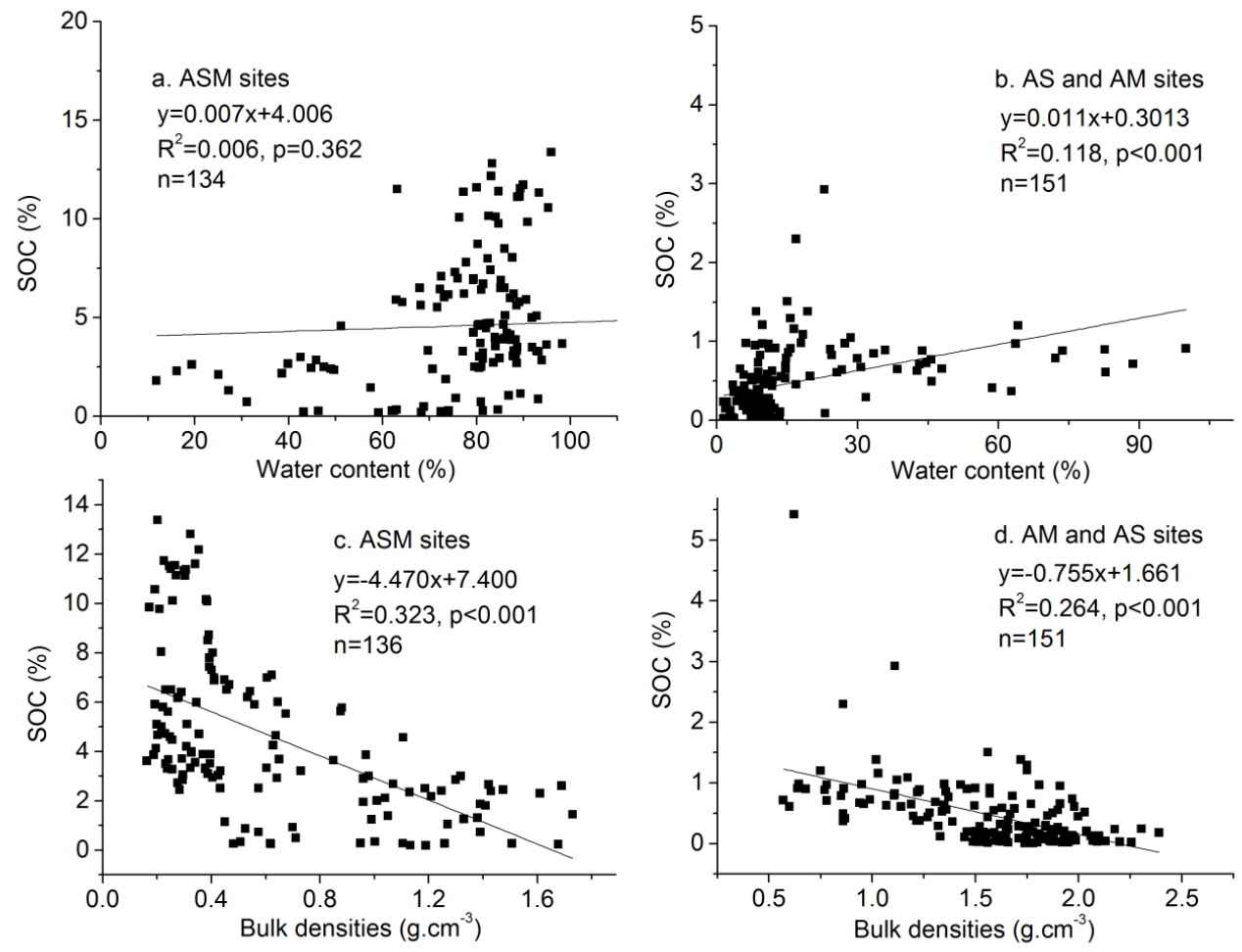

Figure 4 Correlations between SOC and water content, bulk density for ASM, AS, and AM sites (ASM: alpine swamp meadow; AS: Alpine steppe; AM: Alpine meadow) 
The Cryosphere Discuss., doi:10.5194/tc-2016-65, 2016

Manuscript under review for journal The Cryosphere

Published: 20 April 2016

(c) Author(s) 2016. CC-BY 3.0 License.

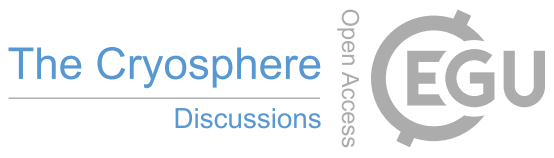

(c) (i)
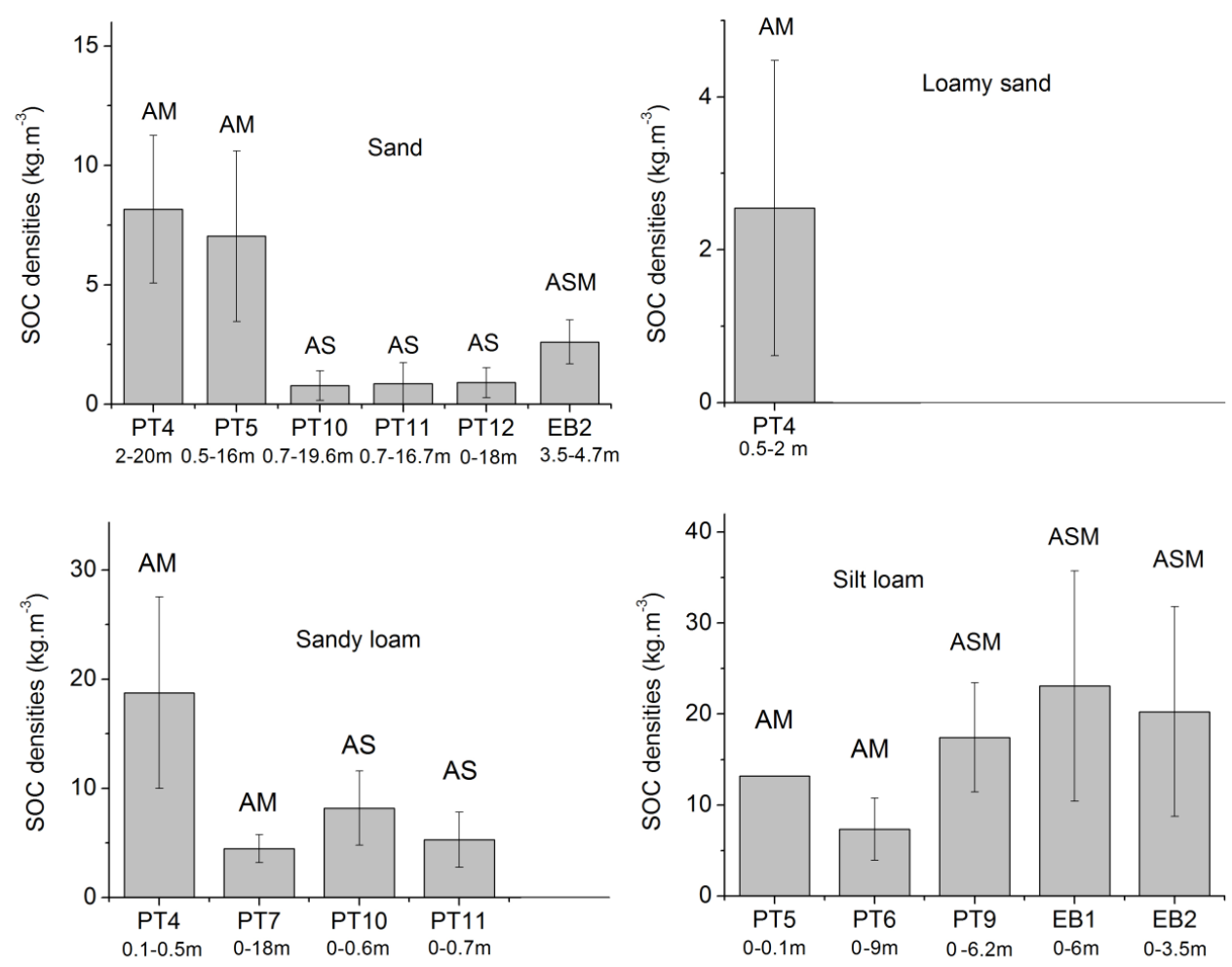

Figure 5 SOC densities in different soil textures at different depths under different vegetation types (ASM: alpine swamp meadow; AS: Alpine steppe; AM: Alpine meadow) 
The Cryosphere Discuss., doi:10.5194/tc-2016-65, 2016

Manuscript under review for journal The Cryosphere

Published: 20 April 2016

(c) Author(s) 2016. CC-BY 3.0 License.

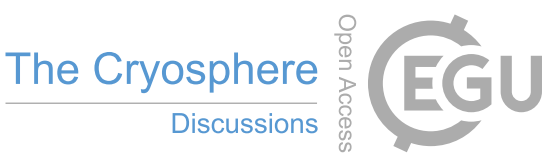

(c) (i)
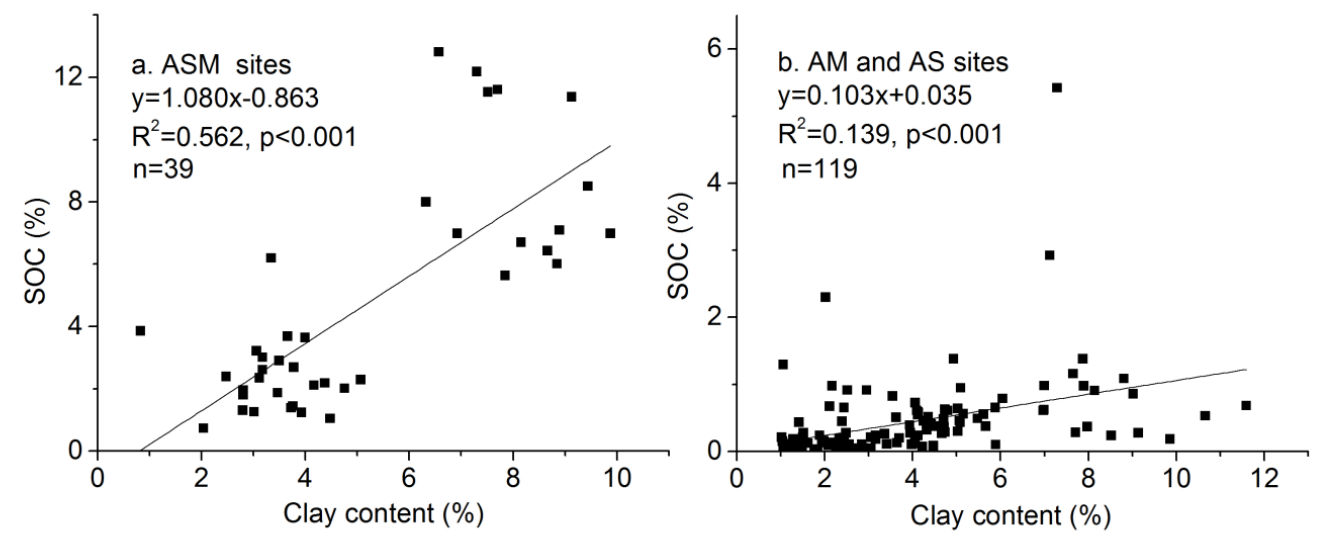

Figure 6 Correlations between SOC and clay contents for ASM, AS and AM sites (ASM: alpine swamp meadow; AS: Alpine steppe; AM: Alpine meadow) 